\title{
Confined Zone Dispersion Project: A DOE Assessment
}

November 1999

U.S. Department of Energy

National Energy Technology Laboratory

P.O. Box 880, 3610 Collins Ferry Road

Morgantown, West Virginia 26507-0880

and

P.O. Box 10940, 626 Cochrans Mill Road

Pittsburgh, Pennsylvania 15236-0940 


\section{Disclaimer}

This report was prepared as an account of work sponsored by an agency of the United States Government. Neither the United States Government nor any agency thereof, nor any of their employees, makes any warranty, express or implied, or assumes any legal liability or responsibility for the accuracy, completeness, or usefulness of any information, apparatus, product, or process disclosed, or represents that its use would not infringe privately owned rights. Reference herein to any specific commercial product, process, or service by trade name, trademark, manufacturer, or otherwise does not necessarily constitute or imply its endorsement, recommendation, or favoring by the United States Government or any agency thereof. The views and opinions of authors expressed herein do not necessarily state or reflect those of the United States Government or any agency thereof. 


\section{Contents}

\section{Page}

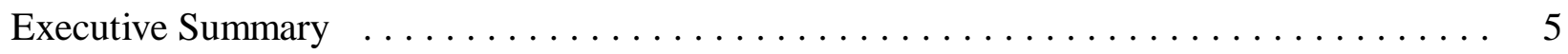

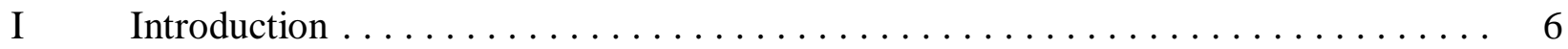

II Technical and Environmental Assessment $\ldots \ldots \ldots \ldots \ldots \ldots \ldots \ldots \ldots \ldots$

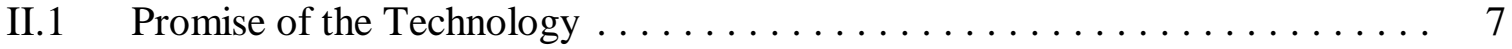

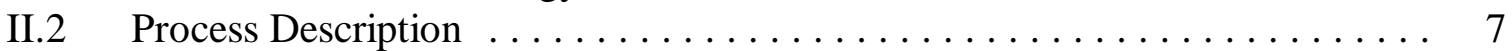

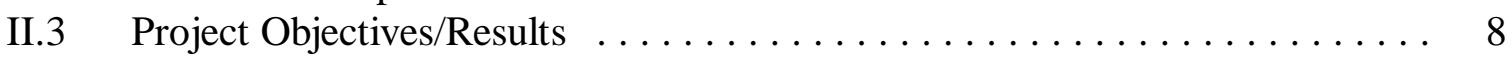

II.4 Environmental Performance $\ldots \ldots \ldots \ldots \ldots \ldots \ldots \ldots \ldots \ldots \ldots \ldots$

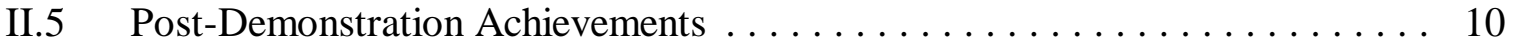

III Operating Capabilities Demonstrated $\ldots \ldots \ldots \ldots \ldots \ldots \ldots \ldots \ldots \ldots \ldots \ldots \ldots$

III.1 Size of Unit Demonstrated $\ldots \ldots \ldots \ldots \ldots \ldots \ldots \ldots \ldots \ldots \ldots \ldots \ldots$

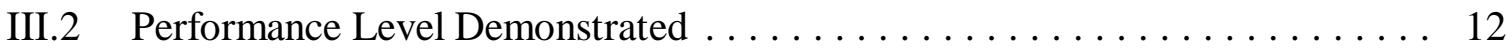

III.3 Major Operating and Design Variables Studied ................. 14

III.4 Operating Problems and Boiler Impacts $\ldots \ldots \ldots \ldots \ldots \ldots \ldots \ldots \ldots \ldots$

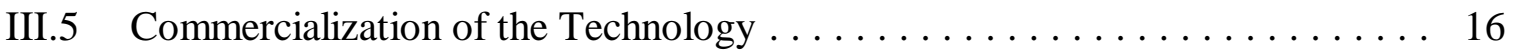

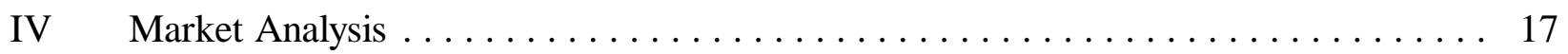

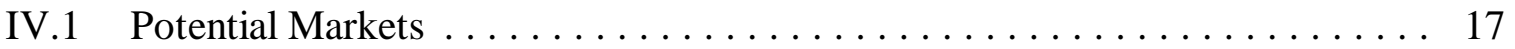

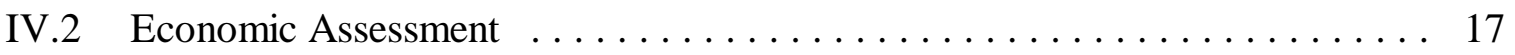

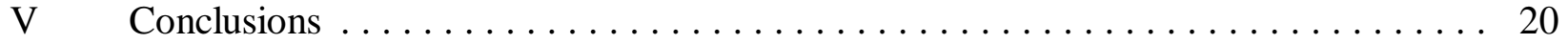

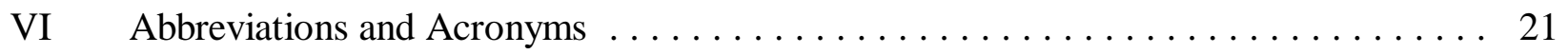

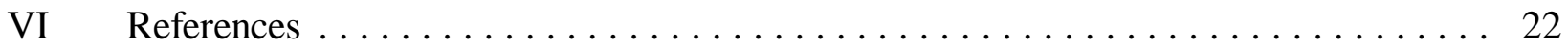




\section{List of Figures and Tables}

Figures $\quad$ Page

1 Seward Station Overall Process Flow Diagram $\ldots \ldots \ldots \ldots \ldots \ldots$

2 Confined Zone Dispersion Diagram $\ldots \ldots \ldots \ldots \ldots \ldots \ldots \ldots \ldots \ldots \ldots$

$3 \quad \mathrm{SO}_{2}$ Removal Versus Lime Slurry Concentration $\ldots \ldots \ldots \ldots \ldots \ldots \ldots \ldots$

4 Lime Utilization Versus Lime Slurry Concentration . . . . . . . . . . . . . 13

Tables $\quad$ Page

$1 \quad$ Test Coal Properties $\ldots \ldots \ldots \ldots \ldots \ldots \ldots \ldots \ldots \ldots \ldots \ldots \ldots \ldots \ldots$

2 Performance Summary: Maximum $\mathrm{SO}_{2}$ Removal Rates $\ldots \ldots \ldots \ldots \ldots \ldots$

3 Summary of Performance and Cost Data, 1994 Dollars . . . . . . . . . . 18 


\section{Executive Summary}

This document serves as a U.S. Department of Energy (DOE) post-project assessment of a project in Clean Coal Technology (CCT) Round 3, entitled "Confined Zone Dispersion Project." In 1990, Bechtel Corporation entered into an agreement to conduct this project with the Seward Power Station of Pennsylvania Electric Company (now GPU Genco) serving as the host site. DOE provided 43 percent of the total project cost of $\$ 12$ million. Other participants were the Pennsylvania Energy Development Authority (PEDA), the New York State Electric and Gas Corporation (NYSEG), and the Rockwell Lime Company. The DOE-sponsored demonstration was conducted between June 1990 and June 1993, with Bechtel supporting additional testing in early 1994.

The Confined Zone Dispersion (CZD) process is a flue gas desulfurization (FGD) process designed to remove sulfur dioxide $\left(\mathrm{SO}_{2}\right)$ produced in a coal-fired utility boiler. The process involves injecting a finely atomized slurry of reactive lime into the duct work. The lime in the slurry droplets reacts with $\mathrm{SO}_{2}$ in the gas, and the reaction products dry to form solid particles. An electrostatic precipitator (ESP) downstream from the point of injection captures the reaction products, along with the fly ash entrained in the flue gas. The CZD process is technically simple and, because it is relatively easy to retrofit with existing equipment, had been projected to have lower capital cost than other FGD processes.

The primary objectives of this project were to:

- Demonstrate an $\mathrm{SO}_{2}$ removal rate of 50 percent with 50-percent sorbent utilization.

- $\quad$ Achieve projected commercial scale $\mathrm{SO}_{2}$ removal costs $\leq \$ 300 /$ ton.

- $\quad$ Ensure that there are no negative effects on normal boiler operations, such as increased particulate emissions or opacity.

The $\mathrm{SO}_{2}$ removal performance objectives were not met. In short-term tests, the target level of 50-percent $\mathrm{SO}_{2}$ removal was achieved, but was not maintained in long-term operation. Lime sorbent utilization at 50-percent $\mathrm{SO}_{2}$ removal was only about 40 percent.

The projected 30-year levelized cost (constant dollar basis) for a 500-megawatt electric (MWe) unit burning 3.9-percent sulfur coal is $\$ 240 /$ ton of $\mathrm{SO}_{2}$ removed. This is lower than the target figure of $\$ 300 /$ ton, but CZD would not be competitive with present day wet FGD processes that achieve 95-percent $\mathrm{SO}_{2}$ removal.

CZD system availability and mechanical operation of the process were very good. During normal operation, no deposits of fly ash or reaction products occurred in the flue gas duct.

The CZD process has not been commercialized. In the United States, compliance with $\mathrm{SO}_{2}$ emissions regulations has been achieved primarily through fuel switching or purchase of emissions allowances. It is not clear whether CZD would find a niche if a market were to develop for FGD processes having limited emissions reduction capability, i.e., 40- to 70-percent $\mathrm{SO}_{2}$ removal. 


\section{Introduction}

The goal of the U.S. Department of Energy (DOE) Clean Coal Technology (CCT) program is to furnish the energy marketplace with a number of advanced, more efficient, and environmentally responsible coal utilization technologies through demonstration projects. These projects seek to establish the commercial feasibility of the most promising advanced coal technologies that have developed beyond the proof-of-concept (POC) stage.

This document serves as a DOE post-project assessment of the Confined Zone Dispersion Project in CCT Round 3. The Project is described in Bechtel Corporation's report to Congress (1990) and papers by Abrams, Rubin, and Baldwin (1992) and Battista, Rubin, Abrams, and Baldwin (1993). The project is also discussed in a DOE update on the CCT program (1997).

In 1990, Bechtel Corporation entered into a cooperative agreement to conduct the demonstration project. The Seward Power Station of Pennsylvania Electric Company (now GPU Genco) was the host site. DOE funded 43 percent of the total project cost of $\$ 12,173,000$.

The project was started in June 1990 and was scheduled to be completed in June 1993. As a result of various operating problems, the schedule was extended into 1994 without additional cost to DOE. Bechtel provided the additional financing and GPU Genco provided electricity, steam, and water to operate the unit. The independent evaluation contained herein is based primarily on information from Bechtel's final technical report (1994) as well as other references cited.

Confined Zone Dispersion (CZD) is a flue gas desulfurization (FGD) process that removes sulfur dioxide $\left(\mathrm{SO}_{2}\right)$. A finely atomized slurry of reactive lime, calcium hydroxide or $\mathrm{Ca}(\mathrm{OH})_{2}$, is injected into the flue-gas duct work, between the air preheater and the second-stage ESP. The lime reacts with the $\mathrm{SO}_{2}$, forming dry solid reaction products. The downstream ESP captures the reaction products along with the fly ash entrained in the flue gas.

The Seward Power Station is located in Western Pennsylvania, approximately 12 miles northwest of Johnstown in East Wheatfield Township, Indiana County. The CZD process was demonstrated on Unit 5, a 147-MWe utility unit with two flue gas ducts. One of the ducts was extended to provide the requisite residence time and retrofitted with the CZD lime injection equipment. 


\section{Technical and Environmental Assessment}

\section{II.1 Promise of the Technology}

This project was undertaken to evaluate the technical and economic feasibility of using the CZD process in a coal-fired utility system to reduce emissions of $\mathrm{SO}_{2}$ by 50 percent. This demonstration, which involved commercial scale implementation of the technology, was supported by the results of previous studies and POC tests by Bechtel Corporation.

The process removes $\mathrm{SO}_{2}$ from the flue gas of a coal-fired utility boiler by reaction with lime, which is injected as a finely atomized slurry into the duct work upstream of the particulate removal equipment. The CZD process offers a technically simple method for 50-percent $\mathrm{SO}_{2}$ removal. If demonstrated successfully, this technology could be beneficial in situations where environmental regulations do not require greater $\mathrm{SO}_{2}$ removal rates.

Bechtel conceived the CZD process in 1984. Two years later, DOE selected the process for POC testing at 5-MWe scale. These initial tests were performed using a slipstream of flue gas from a Consumers Power Company station in Michigan. Test results showed more than 50percent $\mathrm{SO}_{2}$ removal. Larger-scale POC tests were subsequently performed at GPU Genco's Seward Station Unit No. 5. The results of the latter tests confirmed that a true confined zone could be obtained and that proper operation could prevent duct deposits.

Results of these tests were sufficiently promising to convince Bechtel that the CZD process was ready for commercial demonstration. Bechtel's proposal for a CZD demonstration project was selected by DOE during Round 3 of the CCT Program.

\section{II.2 Process Description}

The CZD process involves the injection of lime slurry into the flue-gas duct work of a coal-fired boiler. In the presence of water, $\mathrm{SO}_{2}$ from the flue gas is absorbed as sulfurous acid $\left(\mathrm{H}_{2} \mathrm{SO}_{3}\right)$, which, when exposed to lime, reacts to produce calcium and/or magnesium sulfites and sulfates. These solid products are subsequently removed from the flue gas by the downstream particulate-removal equipment. The reactions are shown below.

$$
\begin{array}{lll}
\mathrm{SO}_{2}+\mathrm{H}_{2} \mathrm{O} & \Rightarrow & \mathrm{H}_{2} \mathrm{SO}_{3} \\
\mathrm{H}_{2} \mathrm{SO}_{3}+\mathrm{Ca}(\mathrm{OH})_{2}+2 \mathrm{O}_{2} & \Rightarrow & \mathrm{CaSO}_{4} \cdot 2 \mathrm{H}_{2} \mathrm{O} \\
\mathrm{H}_{2} \mathrm{SO}_{3}+\mathrm{Ca}(\mathrm{OH})_{2} & \Rightarrow & \mathrm{CaSO}_{3} \cdot 2 \mathrm{H}_{2} \mathrm{O} \\
\mathrm{H}_{2} \mathrm{SO}_{3}+\mathrm{Mg}(\mathrm{OH})_{2} & \Rightarrow & \mathrm{MgSO}_{3} \cdot 2 \mathrm{H}_{2} \mathrm{O}
\end{array}
$$

Initially, Bechtel expected that significant removal of nitrogen oxides $\left(\mathrm{NO}_{\mathrm{X}}\right)$ would occur because of the presence of the magnesium hydroxide, $\mathrm{Mg}(\mathrm{OH})_{2}$, in the dolomitic lime. As shown in Equation 4, the $\mathrm{Mg}(\mathrm{OH})_{2}$ forms magnesium sulfite, $\mathrm{MgSO}_{3}$. Although the latter compound 
potentially can react with $\mathrm{NO}_{\mathrm{X}}$, little or no evidence of $\mathrm{NO}_{\mathrm{X}}$ reduction was seen in the demonstration project.

In the CZD process, the wet reaction particles and unreacted lime must dry in a straight run of duct before contacting the duct-turning vanes, particulate removal equipment, or other surfaces. Otherwise, the particles cause buildup and plugging problems. To prevent this, the lime slurry is injected close to the center of the flue-gas duct, parallel to the flow of gas through narrow-angle sprays. Thus, it is possible to obtain a wet zone in the middle of the duct for $\mathrm{SO}_{2}$ removal while maintaining an envelope of hot gas between the wet zone and the duct wall. If the proper slurry concentration and injection rate are used, drying is complete before the droplets contact the walls of the duct.

Sufficient residence time must be provided to accomplish the $\mathrm{SO}_{2}$ removal reactions and to ensure that the droplets are sufficiently dry. For 50-percent removal of $\mathrm{SO}_{2}$, Bechtel calculated the required residence time to be 2 seconds. Longer residence times could be beneficial but would increase capital costs. Residence time was not studied as a variable in this CCT project.

Seward Station's Unit 5 is a 147-MWe utility unit, with two flue gas ducts, each with a capacity equivalent to $73.5 \mathrm{MWe}$. One of the two ducts was retrofitted with CZD equipment. To provide a lime slurry residence time of approximately 2 seconds, this duct was modified to 211 feet long, with a 120-foot straight section. The duct is rectangular, $8 \mathrm{ft} \times 11 \mathrm{ft}$, yielding a cross sectional area of $88 \mathrm{ft}^{2}$. Figure 1 is a flowsheet of the CZD process, and the CZD principle is illustrated in Figure 2.

\section{II.3 Project Objectives/Results}

The primary objectives of this project were to:

- $\quad$ Demonstrate an $\mathrm{SO}_{2}$ removal rate of 50-percent with 50 percent sorbent utilization.

- $\quad$ Achieve projected commercial scale $\mathrm{SO}_{2}$ removal costs at $\leq \$ 300 /$ ton.

- $\quad$ Ensure that there are no negative effects on normal boiler operations, such as increased particulate emissions or opacity.

The test program at Seward Station showed that the CZD FGD system is applicable to flue gas from a typical boiler burning medium-sulfur coal. However, the target $\mathrm{SO}_{2}$ removal rate of 50 percent was not demonstrated in sustained operation, and lime sorbent utilization was less than 50 percent. Parametric testing showed that higher levels of sorbent utilization can be reached only at the expense of $\mathrm{SO}_{2}$ removal. Although the desired combination of 50-percent $\mathrm{SO}_{2}$ removal and 50-percent sorbent utilization was not attained, sustained operation at lower $\mathrm{SO}_{2}$ removal rates was demonstrated without significant operational problems. The CZD process was found to meet the economic criterion established for the project. 


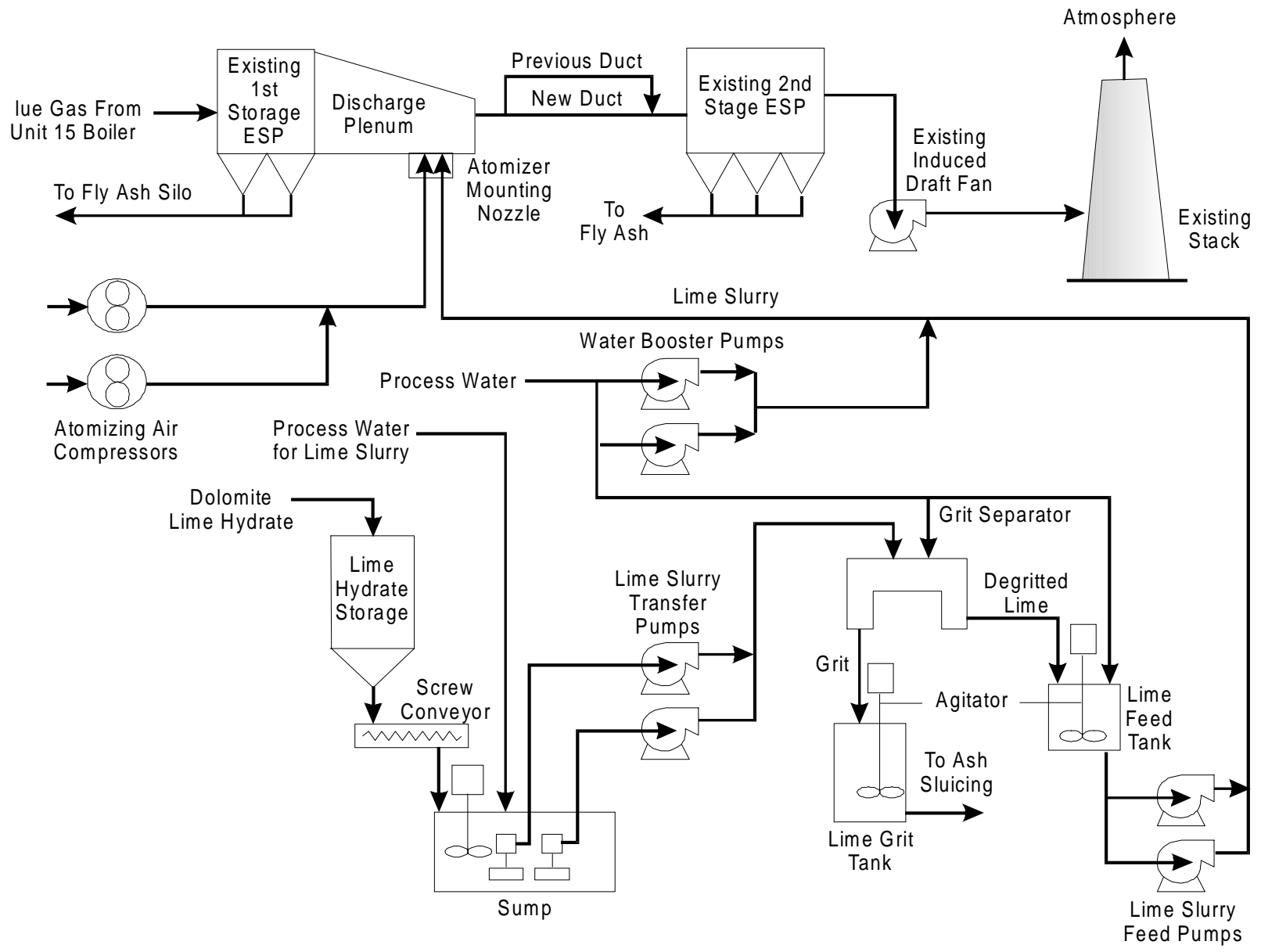

Figure 1. Seward Station Overall Process Flow Diagram

\section{II.4 Environmental Performance}

The CCT project demonstrated two significant environmental benefits. First, it reduced $\mathrm{SO}_{2}$ emissions by up to 50 percent, and second, it improved ESP performance. The enhanced ESP performance was very likely a result of reduced resistivity for some of the ash, increased water vapor in the flue gas, agglomeration of fly ash particles, and cooler flue gas, which increases the residence time. 


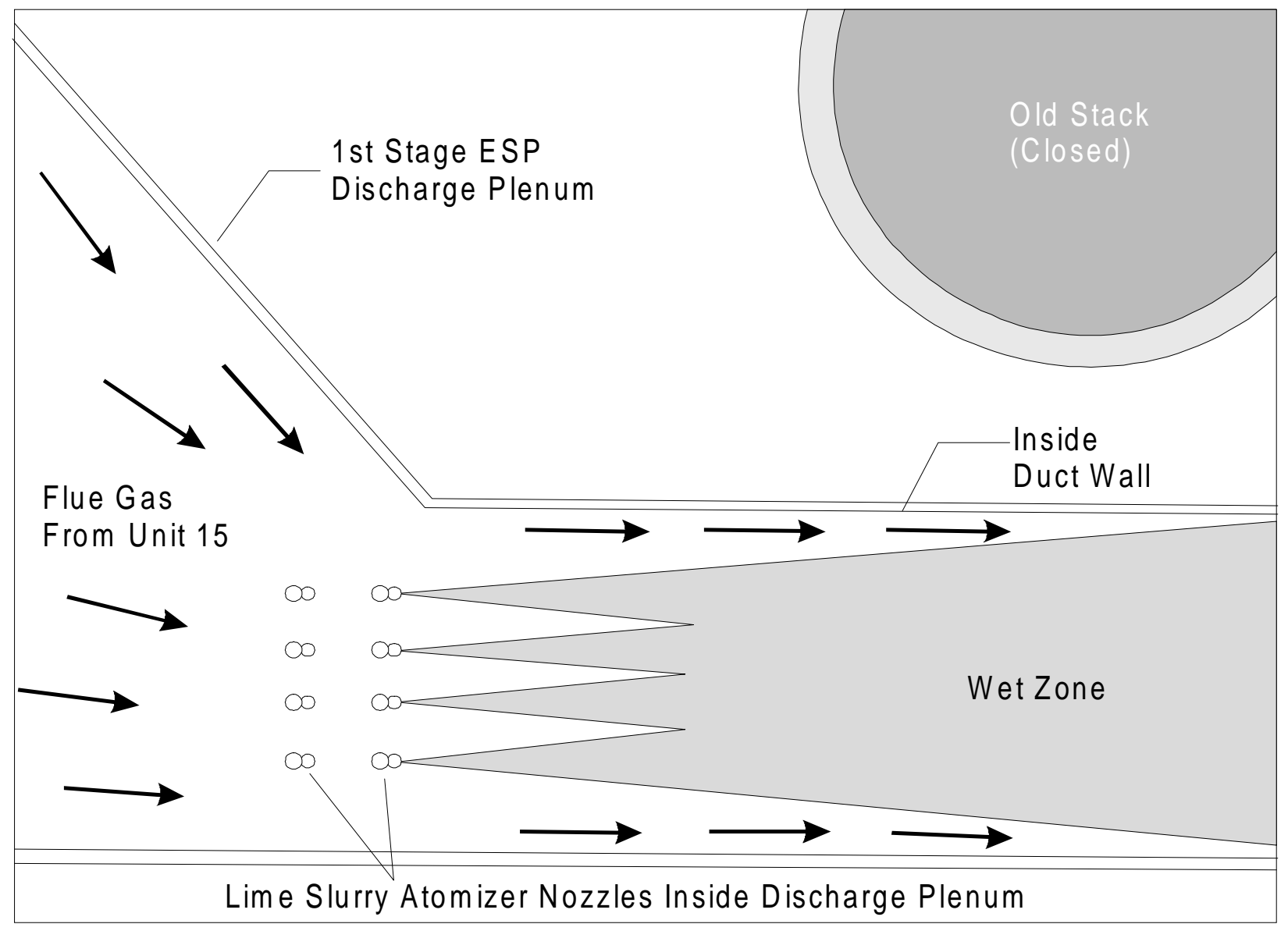

MM000019C

Figure 2. Confined Zone Dispersion Diagram

\section{II.5 Post-Demonstration Achievements}

Subsequent to completion of the DOE-funded CZD demonstration project at Seward Station in 1993, operation of the CZD unit continued, but the desired level of $\mathrm{SO}_{2}$ removal was not achieved. The CZD unit is no longer in service. Bechtel has offered to sell the technology and associated patents because of a conflict of interest, since Bechtel provides consulting services in the area of FGD technology. 


\section{Operating Capabilities Demonstrated}

\section{III.1 Size of Unit Demonstrated}

The demonstration project was conducted at GPU Genco's Seward Power Station, Unit 5, using one of two existing flue gas ducts, each having a capacity equivalent to $73.5 \mathrm{MWe}$. The critical parameters involved in this technology are (1) the maximum volume of slurry that can be injected per unit of cross-sectional area without causing deposition in the duct, (2) the length of the duct required for evaporation of the atomized slurry, and (3) the inlet flue gas temperature. The first two parameters are dependent on boiler and duct size, but can be directly scaled up or down. The third parameter, inlet flue gas temperature, is independent of boiler or duct size.

An analysis of the design coal burned in the demonstration project is given in Table 1. The design coal had a nominal sulfur content of 1.6 percent. Tests were also conducted with higher-sulfur coals (2.1 to 2.4 percent) to determine the effect on CZD performance.

Table 1. Test Coal Properties

\begin{tabular}{|l|c|}
\hline Coal Source & Midwestern Bituminous \\
\hline Proximate Analysis, wt\% (as received) & \\
Fixed Carbon & 42.72 \\
Volatile Matter & 35.57 \\
Moisture & 6.39 \\
Ash & $\underline{15.32}$ \\
Total & $\mathbf{1 0 0 . 0 0}$ \\
\hline Higher Heating Value, Btu/lb & \\
As Received & 12,000 \\
Dry & 12,820 \\
\hline Higher Heating Value, MJ/kg & 27.9 \\
As Received & 29.8 \\
Dry & \\
\hline Ultimate Analysis, wt\% (as received) & 72.41 \\
Carbon & 4.19 \\
Hydrogen & 1.60 \\
Sulfur & 4.14 \\
Oxygen & 1.29 \\
Nitrogen & 16.37 \\
Ash & $\mathbf{1 0 0 . 0 0}$ \\
Total & \\
\hline
\end{tabular}




\section{III.2 Performance Level Demonstrated}

\section{$\mathrm{SO}_{2}$ Emissions Reduction}

Sulfur removal tests were performed with three different reagents: pressure hydrated dolomitic lime (PHDL), hydrated calcitic lime, and freshly slaked calcitic lime. PHDL tests were performed in both a parametric mode, where the effects of slurry feed rate and lime slurry concentration were determined in a series of short ( 1 to 4 hours) tests, and a continuous mode (4 to 20 hours) where the optimum conditions from the parametric tests were utilized. The hydrated and freshly slaked calcitic lime tests were of short duration (1 to 5 hours) with varying slurry feed rates and slurry concentration.

Maximum sulfur removal rates for the four series are indicated in Table 2. Slightly less than 50-percent $\mathrm{SO}_{2}$ removal was achieved with PHDL and slaked lime in the parametric mode. Continuous testing with PHDL resulted in about 46-percent $\mathrm{SO}_{2}$ removal. The poorest performance, about 32 percent removal, was achieved with hydrated calcitic lime.

Table 2. Performance Summary: Maximum $\mathrm{SO}_{2}$ Removal Rates

\begin{tabular}{|l|c|c|c|c|c|c|}
\hline Reagent & Test & $\begin{array}{c}\text { Lime Slurry } \\
\text { Duration, } \\
\mathrm{hr}\end{array}$ & $\begin{array}{c}\text { Calcium/ } \\
\text { Concentration, } \\
\text { wt } \%\end{array}$ & $\begin{array}{c}\text { So } \\
\text { Sulfur Molar } \\
\text { Feed Ratio }\end{array}$ & $\begin{array}{c}\text { Lime } \\
\text { Removal, } \\
\%\end{array}$ & $\begin{array}{c}\text { Utilization, } \\
\%\end{array}$ \\
\hline $\begin{array}{l}\text { Pressure Hydrated } \\
\text { Dolomitic Lime } \\
\text { (PHDL) }\end{array}$ & Parametric & 1.0 & 8.4 & 1.13 & 49.7 & 44.2 \\
\hline $\begin{array}{l}\text { Pressure Hydrated } \\
\text { Dolomitic Lime } \\
\text { (PHDL) }\end{array}$ & Continuous & 7.8 & 9.0 & 1.26 & 46.8 & 37.2 \\
\hline $\begin{array}{l}\text { Hydrated Calcitic } \\
\text { Lime }\end{array}$ & Parametric & 4.9 & 11.1 & 1.15 & 31.7 & 27.5 \\
\hline $\begin{array}{l}\text { Slaked Calcitic } \\
\text { Lime }\end{array}$ & Parametric & 1.1 & 10.5 & 1.48 & 48.8 & 33.0 \\
\hline
\end{tabular}

Based on the data summarized in Table 2, PHDL appears to be the sorbent of choice, demonstrating essentially 50-percent $\mathrm{SO}_{2}$ removal at about 40-percent lime utilization. This performance level was used by Bechtel in projecting commercial economics, discussed in a subsequent section. These data are not entirely consistent with the results shown in Figures 3 and 4 , but no attempt was made to reconcile the differences. 


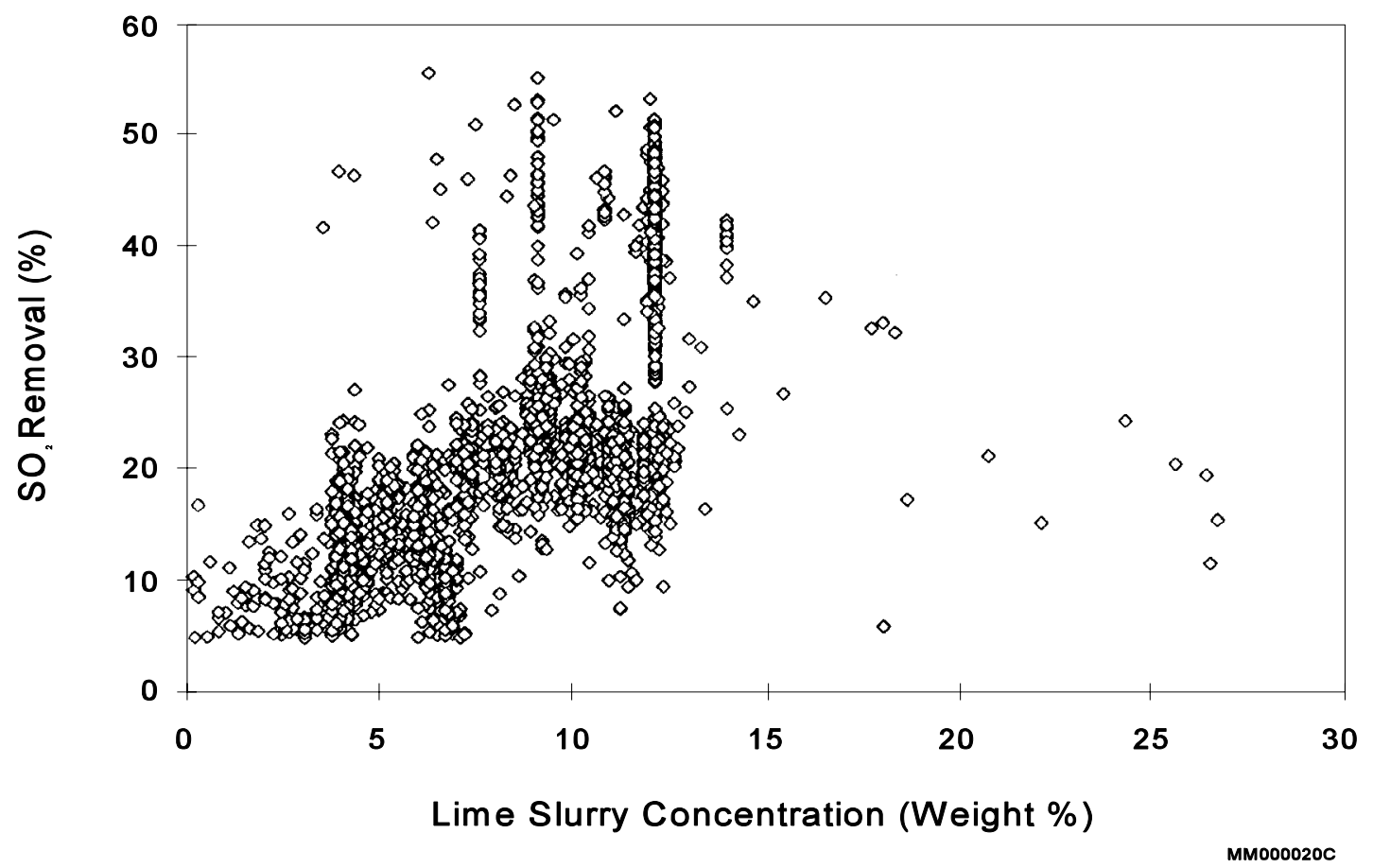

Figure 3. $\mathrm{SO}_{2}$ Removal Versus Lime Slurry Concentration

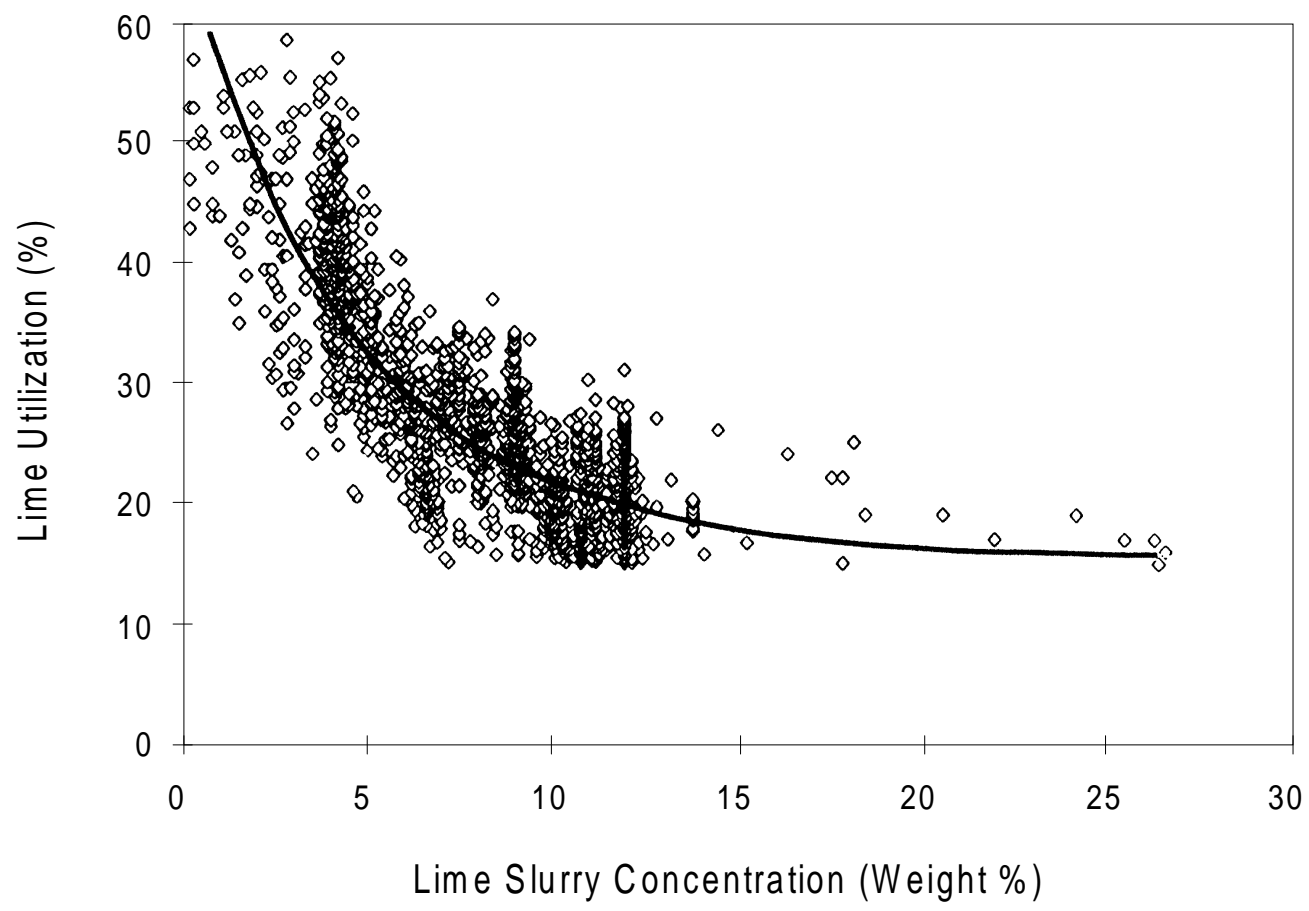

Figure 4. Lime Utilization Versus Lime Slurry Concentration 


\section{Duct Deposits}

Duct deposits were not significant during normal operation of the CZD system. However, notable duct deposits did occur on two occasions. These resulted from a low soot-blower steamsupply pressure and plugged nozzles, which resulted in unstable lime injection. After these problems were corrected, normal operations were resumed.

\section{ESP Performance}

The CZD system had a beneficial effect on ESP performance, as indicated by a decrease in stack opacity during reagent injection. Agglomeration of ash particles, higher water content, cooler flue gas with increased residence time, and possible reduced resistivity for some ash were suggested as possible contributing factors.

\section{III.3 Major Operating and Design Variables Studied}

Bechtel's final technical report on the CZD project (1994) summarizes the effects of key operating variables on $\mathrm{SO}_{2}$ removal, i.e., lime slurry injection rate, lime-slurry concentration, flue gas temperature, and coal sulfur content. The parametric studies showed the following:

- At lime slurry concentrations ranging from 7.5 to $12 \mathrm{wt} \%$ and $\mathrm{Ca} / \mathrm{S}$ molar feed ratios ranging from about 1.0 to $1.8, \mathrm{SO}_{2}$ removal is directly proportional to the volumetric limeslurry feed-rate.

- At a constant lime-slurry feed-rate with varying lime concentration, $\mathrm{SO}_{2}$ removal increases from about 10 to 20 percent at a lime concentration of about 3 to $5 \mathrm{wt} \%$, to a maximum of about 50 percent at a lime concentration of about $12 \mathrm{wt} \%$. Above that level, an increase in lime concentration does not increase the percentage of $\mathrm{SO}_{2}$ removed. At the same time, lime utilization decreases from a maximum exceeding 50 percent at low lime concentration to about 15 to 20 percent at the higher lime concentration. These effects are shown graphically in Figures 3 and 4.

The results of these parametric tests are not entirely consistent with the data summarized in Table 2, where an $\mathrm{SO}_{2}$ removal rate of 50 percent was achieved at 40-percent lime utilization. In Figure 3, which has considerable scatter of the data points, 50-percent $\mathrm{SO}_{2}$ removal generally occurs at lime slurry concentrations of about 9 to $12 \mathrm{wt} \%$. At that level of lime slurry concentration, lime utilization is only about 20 percent. No attempt was made to reconcile this apparent contradiction.

- The maximum lime slurry feed rate is a function of geometry of the flue gas duct, straight length of duct between the injection point and turning vanes, flue gas velocity in the duct, duct inlet temperature, and degree of atomization of the lime slurry. The slurry feed rate ranged from 30 to $50 \mathrm{gpm}$. With a duct cross sectional area of $88 \mathrm{ft}^{2}$, this represents a 
superficial velocity ranging from $0.34 \mathrm{gpm} / \mathrm{ft}^{2}$ to $0.57 \mathrm{gpm} / \mathrm{ft}^{2}$. The superficial velocity can be scaled to larger or smaller equipment.

- A separate series of tests was run to evaluate the effect of coal sulfur content on $\mathrm{SO}_{2}$ removal. For higher-sulfur coal (2.1 to 2.4 percent sulfur), $\mathrm{SO}_{2}$ removal rates were somewhat higher than with the design coal (1.6 percent sulfur). In this test series, maximum $\mathrm{SO}_{2}$ reduction with the higher-sulfur coal was 44.3 percent compared to 36.2 percent for the design coal. These results can be attributed to the higher $\mathrm{SO}_{2}$ concentration in the flue gas, which provides a greater driving force for the reaction between $\mathrm{SO}_{2}$ and the reagent.

In the economic analysis presented in a subsequent section, Bechtel assumed a coal feed sulfur content of $3.9 \mathrm{wt} \%$. While a sulfur level this high was not tested in the demonstration project, there is no reason to believe that the CZD process would not be applicable to such coal feeds.

- $\quad$ The approach to the adiabatic saturation temperature was found to be an important factor in determining $\mathrm{SO}_{2}$ removal. The smaller the approach, the greater the moisture content of the flue gas. The highest $\mathrm{SO}_{2}$ removal can be obtained at the lowest possible approach. The lowest approach temperature during the demonstration was $40{ }^{\circ} \mathrm{F}$ at the turning vanes; a lower approach temperature was found to cause sticky deposits and unwanted buildup. To maintain the $40{ }^{\circ} \mathrm{F}$ approach to saturation required an inlet flue gas temperature above $300{ }^{\circ} \mathrm{F}$. In cases where the flue gas temperature fell below $300{ }^{\circ} \mathrm{F}$, the lime injection rate had to be reduced, resulting in lower $\mathrm{SO}_{2}$ removal rates.

\section{III.4 Operating Problems and Boiler Impacts}

Several operating problems arose during the demonstration project. These problems were analyzed and corrected, resulting in improved performance and operation in all cases. The problem areas were as follows.

- $\quad$ Atomizer Plugging - After periods when the unit was not active, plugging occurred in the lime slurry pipes feeding the atomizers. The problem was remedied by recirculating the feed slurry through the vibrating screen in the slurry feed preparation circuit for several hours before injection into the atomizers.

- $\quad$ Atomizer Tip Deposits - In early experimental runs, deposits were found on the duct floor and the turning vanes which required removal. These deposits were thought to be the result of inadequate atomization of the slurry and less-than-predicted entrainment of the lime droplets in the flue gas. After the atomizer tips were modified, testing resulted in no further deposits in the duct. 
- $\quad$ Lime System Deposits and Hardware Failures — Lime slurries tend to deposit solids on all exposed surface. These deposits are minimized if the lime slurry equipment is always filled and recirculating. Valve and pump failures were experienced but were corrected using control valves with ceramic internals, repacking the pump seals with the proper packing, and replacing a faulty wear plate. Bechtel was not able to resolve the difficulty of being able to determine when a nozzle is broken or malfunctioning.

- Boiler Performance - Because the demonstration involved only post-combustion treatment of the flue gas, the CZD operation had no effect on boiler performance.

\section{III.5 Commercialization of the Technology}

The CZD process can be scaled to fit a variety of plant capacity requirements. A major consideration is the need to provide sufficient residence time in a straight duct to achieve the desired level of $\mathrm{SO}_{2}$ removal. If existing duct work is inadequate, it may be possible to install new duct work designed to provide the required residence time, as done in the Seward Station CZD demonstration project.

The DOE-funded demonstration at Seward Station proved the reliability of the CZD process, but long-term, continuous operation at the target level of 50 percent or more $\mathrm{SO}_{2}$ removal was not achieved. GPU Genco is no longer operating the CZD process at Seward Station, and Bechtel has offered the process and patents for sale. 


\section{Market Analysis}

\section{IV.1 Potential Markets}

The CZD process can be used for retrofit of existing boilers, independent of boiler type, age, and size, as well as rank and sulfur content of the coal burned. Whereas conventional wet scrubbers are designed for $\mathrm{SO}_{2}$ removal of 95 percent or more, the CZD process was designed to achieve limited removal, nominally about 50 percent, at a potentially lower cost.

The acid rain provisions of the 1990 Clean Air Act Amendments (CAAA) give utilities the option to select the most cost-effective approach to control $\mathrm{SO}_{2}$ emissions to required levels. Effective January 1, 2000, the $\mathrm{SO}_{2}$ emissions limit under Title IV is $1.2 \mathrm{lb} / 10^{6} \mathrm{Btu}$. For a typical eastern bituminous coal containing 3-percent sulfur and having a higher heating value of 12,000 $\mathrm{Btu} / \mathrm{lb}$, the uncontrolled $\mathrm{SO}_{2}$ emissions are about $5 \mathrm{lb} / 10^{6} \mathrm{Btu}$. To meet the forthcoming emissions regulation would require about 75-percent $\mathrm{SO}_{2}$ reduction. Clearly, CZD is not capable of this level of performance.

CZD is potentially suitable for applications where limited $\mathrm{SO}_{2}$ removal, i.e., 40 to 50 percent reduction, could be used to offset emissions elsewhere in a utility system. However, it is now common in the utility industry to switch to low sulfur fuels or purchase $\mathrm{SO}_{2}$ emissions allowances, with the result that few FGD units of any kind are being installed.

Competing technologies are likely to be those that also have limited $\mathrm{SO}_{2}$ removal capability. As discussed subsequently, sorbent injection technologies, including CZD, meet this criterion. Comparative performance and costs on a site-specific basis will determine process choice.

\section{IV.2 Economic Assessment}

\section{CZD Costs}

A preliminary economic assessment for commercial application of the CZD process at various unit capacities is included in Bechtel's final technical report (1994). It was assumed that no existing equipment would be available and a complete lime receiving, preparation, and storage system would be required. The cost estimate allows for plant modifications needed to provide the required straight length of duct work, as in the case of the demonstration unit.

The economics for a generic 500-MWe CZD unit are given in Table 3. $\mathrm{SO}_{2}$ removal was assumed to be 50 percent, with 40-percent lime utilization. Bechtel assumed a coal sulfur content of 3.9 percent, although coals with this high a sulfur level were not tested in the demonstration project. The estimated capital cost is $\$ 22$ million, equivalent to $\$ 44$ per kilowatt $(\mathrm{kW})$. Based on a project life of 30 years, the constant dollar levelized cost is $\$ 240 /$ ton of $\mathrm{SO}_{2}$ removed. On a current dollar basis, the levelized cost is $\$ 383 /$ ton. The projected constant dollar levelized cost 
meets the economic target of $\leq \$ 300 /$ ton established for the demonstration project. Use of a 15year project life would increase the cost, as would a lower coal sulfur content.

Table 3. Summary of Performance and Cost Data, 1994 Dollars

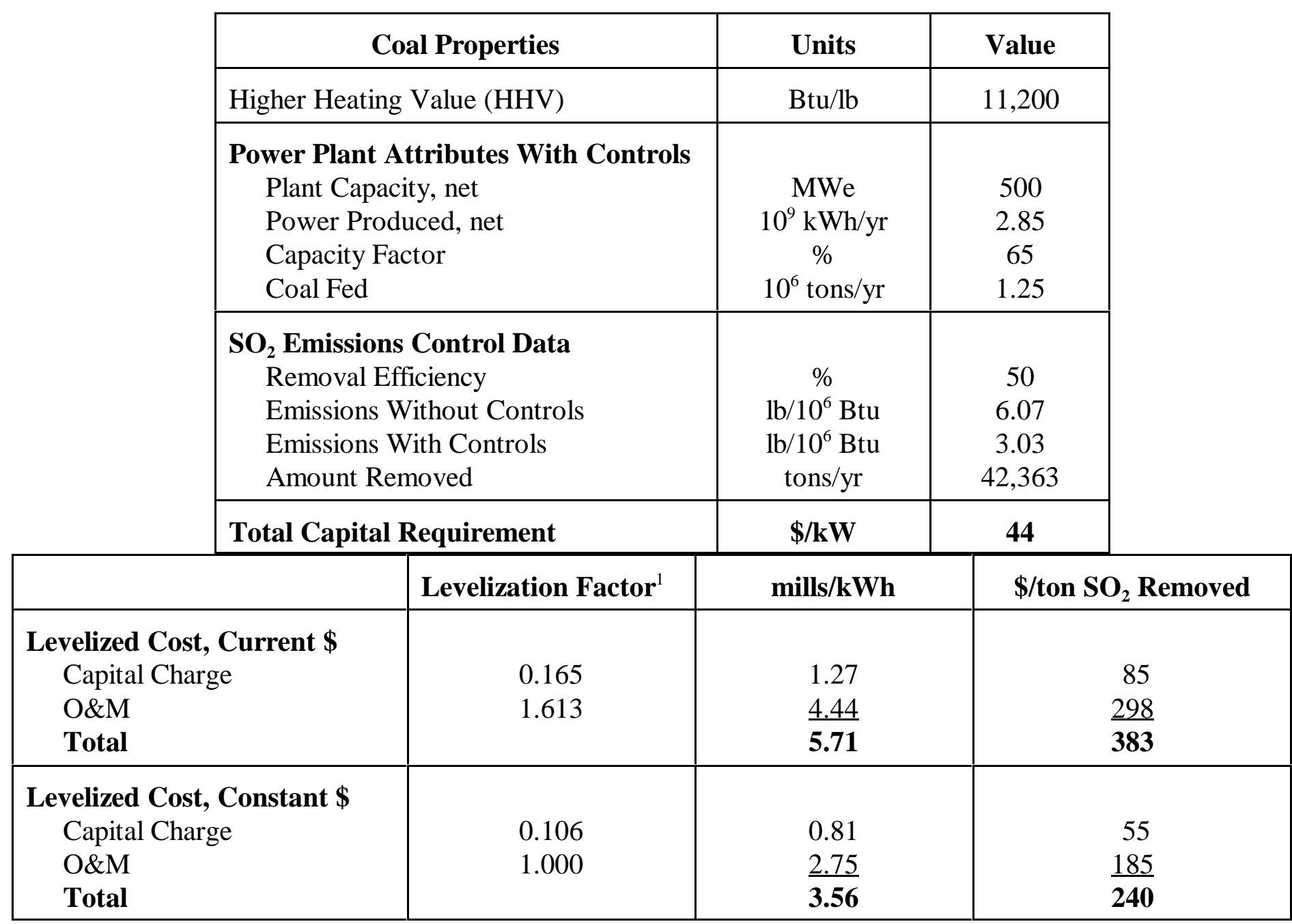

${ }^{1}$ levelization based on 30-year project life

There is an error in the capital cost given in Bechtel's Final Technical Report. In their Table 7-3, the total capital requirement for a 500-MWe CZD installation is correctly stated at the top of the page as $\$ 21.87$ million, but this is incorrectly converted to a figure of $\$ 37.70 / \mathrm{kW}$. The correct figure is $\$ 43.74 / \mathrm{kW}$, which is rounded to $\$ 44 / \mathrm{kW}$ in our Table 3. The incorrect $\$ 37.70 / \mathrm{kW}$ figure is cited in Bechtel's text and in their Executive Summary. The levelized costs reported by Bechtel are correctly calculated, since they are based on the correct $\$ 43.74 / \mathrm{kW}$ capital requirement.

\section{Comparison With Competing Technologies}

The target cost of $\$ 300 /$ ton of $\mathrm{SO}_{2}$ removed, stated in the CZD CCT project proposal, was chosen to be competitive with commercially available wet process FGD technologies. Even 
at that cost, the CZD process would not compete with wet FGD technology having $\geq 95$-percent $\mathrm{SO}_{2}$ removal capability.

CZD would have to compete with other sorbent injection FGD processes having an $\mathrm{SO}_{2}$ removal capability on the order of 40 to 70 percent. These processes include (1) furnace injection, where the sorbent is injected into the combustion zone; and (2) duct injection, where sorbent is injected into the ducts immediately following the furnace. A number of these technologies were evaluated in a two-volume report prepared by EPRI $(1991,1992)$. These processes are summarized as follows:

- $\quad$ Lime Spray Dryer (LSD) - Flue gas is contacted with lime slurry in a spray dryer absorber. The slurry reacts with $\mathrm{SO}_{2}$ to form a solid, which is collected in a baghouse (or ESP) along with the fly ash. Advantages include dry solids handling, while disadvantages include the potential to "blind" fabric filter bags and greater potential for solids buildup on internal duct surfaces.

- $\quad$ Furnace Sorbent Injection (FSI) - Hydrated lime is injected dry into the furnace cavity of the boiler. Water is injected into the duct work downstream of the air heater for flue gas conditioning. Reaction products and fly ash are collected in the ESP.

- $\quad$ Economizer Injection (EI) - This process is identical to FSI except for the location of sorbent injection, which is at the economizer inlet.

- $\quad$ Duct Sorbent Injection (DSI) - Hydrated lime is injected dry into the duct work. Water is injected upstream of the lime injection point (or downstream in some cases) to cool and humidify the flue gas. The solids are collected in the ESP and a portion is recycled and reinjected with fresh sorbent to increase reagent utilization. This process has a low space requirement. A major concern of the DSI process is the long-term effects of wall wetting and the potential for solids deposition.

- $\quad$ Duct Spray Drying (DSD) - Lime slurry is sprayed directly into the duct work. The reaction products and fly ash are captured downstream in the ESP. CZD falls into this category.

The EPRI study, which is based on a plant capacity of 300 MWe, gives capital costs ranging from $\$ 83 / \mathrm{kW}$ for DSD to $\$ 173 / \mathrm{kW}$ for LSD. Thirty-year levelized costs, in 1990 constant dollars, range from $\$ 394 /$ ton of $\mathrm{SO}_{2}$ removed for LSD to $\$ 691 /$ ton for DSI.

The EPRI study did not include an evaluation of the CZD process. As indicated above, CZD is a variation on DSD technology, which has the lowest capital cost of the sorbent injection processes considered. While the cost estimate for CZD in the Bechtel final report (1994) based on 500 MWe cannot be readily scaled to other capacities, CZD does offer a lower capital cost than other sorbent injection processes. 


\section{Conclusions}

The major findings of the CZD demonstration project are as follows:

- The injection of atomized lime slurry in a large duct can be controlled in a confined zone, which minimizes duct deposition while enhancing $\mathrm{SO}_{2}$ removal performance. During normal operation, no deposits of fly ash and reaction products took place in the flue gas duct. Problems with the atomizers and off-design operation can cause solids deposition.

- The target level for $\mathrm{SO}_{2}$ removal of 50 percent, specified in the project objectives, was demonstrated only on a short-term basis, but sustained operation at that removal rate was not accomplished.

- The target of 50-percent lime utilization was not achieved simultaneously with 50-percent $\mathrm{SO}_{2}$ removal. At 50-percent $\mathrm{SO}_{2}$ removal, maximum lime utilization was about 40 percent. Lime utilization has a significant effect on the economics, impacting the cost of both sorbent feed and waste disposal.

- The projected 30-year constant dollar cost for a commercial 500-MWe CZD unit meets the project objective of $\leq \$ 300 /$ ton of $\mathrm{SO}_{2}$ removed. However, CZD would not compete with present day wet FGD processes that remove $\geq 95$ percent of the $\mathrm{SO}_{2}$.

- Additional testing would be required to define the limits of lime injection rates and $\mathrm{SO}_{2}$ removal, and to assess the effect of long-term operation on ESP performance. 


\section{Abbreviations and Acronyms}

$\begin{array}{ll}\text { CAAA } & \text { 1990 Clean Air Act Amendments } \\ \text { Ca(OH })_{2} & \text { calcium hydroxide } \\ \text { CCT } & \text { Clean Coal Technology (Program) } \\ \text { CZD } & \text { confined zone dispersion } \\ \text { DOE } & \text { U.S. Department of Energy } \\ \text { DSI } & \text { duct sorbent injection } \\ \text { DSD } & \text { duct spray drying } \\ \text { EI } & \text { economizer injection } \\ \text { ESP } & \text { electrostatic precipitator } \\ \text { FGD } & \text { flue gas desulfurization } \\ \text { FSI } & \text { furnace sorbent injection } \\ \text { GPU Genco } & \text { formerly Seward Power Station of Pennsylvania Electric Company } \\ \text { H2SO } & \text { sulfurous acid } \\ \text { kW } & \text { kilowatt } \\ \text { LSD } & \text { lime spray dryer } \\ \text { NYSEG } & \text { New York State Electric and Gas Corporation } \\ \text { Mg(OH })_{2} & \text { magnesium hydroxide } \\ \text { MgSO } & \text { magnesium sulfite } \\ \text { MWe } & \text { megawatt electric } \\ \text { NO } & \text { nitrogen oxides } \\ \text { PEDA } & \text { Pennsylvania Energy Development Authority } \\ \text { PHDL } & \text { pressure hydrated dolomitic lime } \\ \text { POC } & \text { proof of concept } \\ \text { SO } & \text { sulfur dioxide } \\ & \end{array}$




\section{References}

Abrams, J.Z, A.G. Rubin, and A.L. Baldwin. November 1992. Update and Results of Bechtel's Confined Zone Dispersion Process Demonstration at Pennsylvania Electric Company's Seward Station, presented at the First Annual Clean Coal Technology Conference, Cleveland Ohio, November 1992.

Battista, J.J., A.G. Rubin, J.Z. Abrams, and A.L. Baldwin. September 1993. Demonstration of Bechtel's Confined Zone Dispersion Process at Pennsylvania Electric Company's Seward Station - Project Status, presented at the Second Annual Clean Coal Technology Conference, Atlanta Georgia, September 1993.

Bechtel Corporation. September 1990. Confined Zone Dispersion, comprehensive report to Congress, Clean Coal Technology Program, U.S. Department of Energy.

Bechtel Corporation. June 1994. Confined Zone Dispersion Project - Final Technical Report.

EPRI. February 1991. Economic Evaluation of Flue Gas Desulfurization Systems - Volume 1.

EPRI. January 1992. Economic Evaluation of Flue Gas Desulfurization Systems - Volume 2.

U.S. Department of Energy. October 1997. Clean Coal Technology Demonstration Program, Program Update. 